\title{
KORRÓZIÓÁLLÓ ACÉL TIG-ELJÁRÁSVÁLTOZATOKKAL HEGESZTETT KÖTÉSEINEK MECHANIKAI VIZSGÁLATA
}

\section{MECHANICAL TESTING OF STAINLESS STEEL JOINTS WELDED BY TIG PROCESS VARIANTS}

\author{
Losonci Kálmán ${ }^{1}$, Bagyinszki Gyula ${ }^{2}$ \\ ${ }^{I}$ ÉLINVEST Kft., Magyarország, 1184 Budapest, Lakatos u. 61-63, \\ losoncikalman@gmail.com \\ ²́budai Egyetem, Bánki Donát Gépész és Biztonságtechnikai Mérnöki Kar, \\ Magyarország, 1081 Budapest, Népszínház u. 8, bagyinszki.gyula@bgk.uni- \\ obuda.hu
}

\begin{abstract}
This article is a review of the welding technology test, what X2CrNi18-9 material quality austenitic stainless steel was performed, examining the main mechanical properties of welded joints. The welded joints between thin sheets, TIG (Tungsten Inert Gas) process, to different process variants made with variable process parameters. The "Return" method as a special case compared with other TIG process variants.
\end{abstract}

Keywords: stainless steel, TIG-welding, autogenous welding, filler metal welding, „Return” welding

\section{Összefoglalás}

Jelen cikkben olyan hegesztéstechnológiai tesztről számolunk be, amit X2CrNi18-9 anyagminőségü ausztenites korrózióálló acélon végeztünk, vizsgálva a hegesztett kötések főbb mechanikai tulajdonságait. A hegesztett kötéseket vékony lemezek között, TIG (Tungsten Inert Gas) eljárással, annak különbözö eljárásváltozataival készítettük, változó technológiai paraméterek mellett. A „Return” eljárásváltozatot, mint speciális esetet hasonlítjuk össze más TIG-eljárásváltozatokkal.

Kulcsszavak: korrózióálló acél, TIG-hegesztés, autogén hegesztés, hozaganyagos hegesztés, „Return” hegesztés

\section{Technológiai kísérletek}

A hegesztéseket argon védőgázas volfrám-elektródás (TIG vagy AWI) ívhegesztéssel, EWM Triton 160 inverteres DC (egyen-áramú) hegesztőgéppel végeztük. A kísérle-tekhez X2CrNi18-9 (1.4307 ausztenites korrózióálló acél) anyagminőségü, hidegen hengerelt, 2,5 mm vastagságú lemezt használtunk, melynek kémiai összetétele: $\mathrm{C}=0,021 \%, \mathrm{Mn}=1,5 \%$,
$\mathrm{Si}=0,5 \%, \quad \mathrm{Cr}=18,29 \%, \quad \mathrm{Ni}=8,01 \%$, $\mathrm{P}=0,026 \%, \quad \mathrm{~S}=0,002 \%$. Fö mechanikai tulajdonságai: $\quad R_{\mathrm{p} 0,2}=283 \quad \mathrm{MPa}, \quad \mathrm{R}_{\mathrm{m}}=647$ MPa, $A=55,6 \%$. Az anyag kiválóan hegeszthetö, alacsony hőmérsékleten is nagy szivósságú, jól mélyhúzható és polírozható.

A hozaganyag nélküli (Autogén, jelölésben: A) és hozaganyagos (TIG rod, jelölésben: Tr) hegesztéseket végeztünk. Ez utóbbiaknál X2CrNiMo19-12 (1.4430 vagy 
1912 3L) anyagminőségü, 2,0 $\mathrm{mm}$ átmérőjü tömör pálcát alkalmaztunk. Ezen hozaganyag összetétele: $\mathrm{C}=0,01 \%$, $\mathrm{Mn}=1,7 \%, \quad \mathrm{Si}=0,79 \%, \quad \mathrm{Cr}=18,2 \%$, $\mathrm{Ni}=12,2 \%, \quad \mathrm{Mo}=2,5 \%, \quad \mathrm{P}=0,027 \%$, $\mathrm{S}=0,002 \%, \quad \mathrm{Cu}=0,1 \%, \quad \mathrm{Nb}<0,01 \%$, $\mathrm{V}<0,001 \%$; fó mechanikai tulajdonságai: $\mathrm{R}_{\mathrm{p} 0,2}=370 \mathrm{MPa}, \mathrm{R}_{\mathrm{m}}=635 \mathrm{MPa}, \mathrm{A}=56 \%$, $\mathrm{KV}=82 \mathrm{~J}$ (-196 ${ }^{\circ} \mathrm{C}$-on). Ezen hozaganyag használata javasolt X2CrNi18-9 alapanyag hegesztéséhez, mivel kedvező korrózióállósági jellemzői vannak.

A tompavarratos hegesztett kötések gépi lemezollóval vágott, 300×125 mm-es lemezdarabok között készültek, melyeket füzővarratokkal pozicionáltunk egymáshoz. Gyökhézag-mentes autogén hegesztéseknél a $7 \mathrm{~mm}$ hosszúságú füzővarratok távolságát $70 \mathrm{~mm}$-re választottuk. Az $1 \mathrm{~mm}$ gyökhézagú hozaganyagos hegesztés előtt a 7 mm hosszúságú füzővarratok $40 \mathrm{~mm}$-es távolságban készültek. A gyökvédelem egyik megoldása alátétlemez alkalmazása, aminek anyaga esetünkben 40 mm széles, 2 $\mathrm{mm}$ vastag vörösréz lemez. Ennek szorosan kell a munkadarabhoz illeszkednie, mivel a nem megfelelő zárás utat enged a levegőnek és a gyökoldalon oxidáció lép fel.

$20{ }^{\circ} \mathrm{C}$-os környezeti hőmérsékleten, $\mathrm{kb}$. $50 \%$-os páratartalom mellett, az 1. ábra szerinti pisztolyfej-kialakítással, 4.6-os (99.996\%) tisztaságú, 10 liter/perc áramlási sebességü, palackos argon védőgázzal hegesztettünk. A védőgáz előáramlását $1 \mathrm{~s}-$ ra, utóáramlását 5 s-ra állítottuk, hogy ívgyújtáskor és varratbefejezéskor is legyen kielégítő gázvédelem. Gázlencsét is alkalmaztunk, hogy a pisztolyból kiáramló gáz turbulenciáját megakadályozzuk, elkerülve a környező levegő bekeveredését. Az elektróda távolsága a munkadarabtól (kísérleteinkben $2 \mathrm{~mm}$ ) a beolvadás és varratalak szempontjából fontos, a pisztoly dőlésszöge $\left(43^{\circ}\right)$ a höbevitelre van hatással.

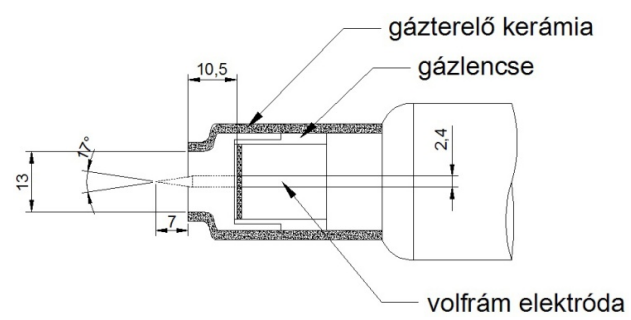

1. ábra. Alkalmazott pisztolyfej kialakitás

Amikor vörösréz alátétlemezes gyöktámasztás (material backing, rövidítésben: mb) helyett védőgázos gyökvédelmet (gas backing, jelölésben: gb) alkalmaztunk, az ehhez használt tér feltöltéséhez szükséges időt 1 percben határoztuk meg, és a védőgázáramot 5 liter/perc-re korlátoztuk. A gázzal feltöltött tér (2) egy oldalain és végein alumínium ragasztószalaggal (1) lezárt U-profil (3), melyet ideiglenesen a gyökoldal alá illesztünk (2. ábra). Fontos a gázáramlás folyamatos biztosítása gáztömlő (5) és pl. 1/4"-os menetes csőcstalakozás (4) segítségével. A feltöltött térből lennie kell egy kiáramlási pontnak is, hogy ne keletkezhessen túlnyomás a hegfürdő alatt, ami a képződő varratot „,deformálhatná”.

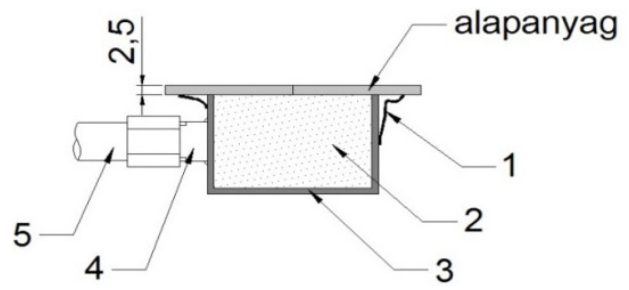

2. ábra. Gyökoldali gázvédelem megoldása

Az autogén és egyoldali (Single Side, jelölésben: SS) tompavarratos hegesztett kötések gyökvédelemmel és anélkül készültek, két-két különböző áramerősség $($ Low $=$ alacsonyabb, High = magasabb; jelölésben: L és H) - hegesztési sebesség kombinációban, azaz különböző fajlagos hőbevitellel. A „Return” (jelölésben: R) vagyis két oldalról egyidőben hegesztő 
eljárásváltozatnál (3. ábra) az áramerősség a két oldalon alkalmazott értékekkel adható meg (pl: $55 / 35$ esetben a korona oldali áramerősség $=55 \mathrm{~A}$, a gyökoldali áramerősség $=35 \mathrm{~A}$ ). A gyökoldali hegesztés a beolvadást biztosítja, valamint a gyökoldalt védi a levegő káros hatásaitól.

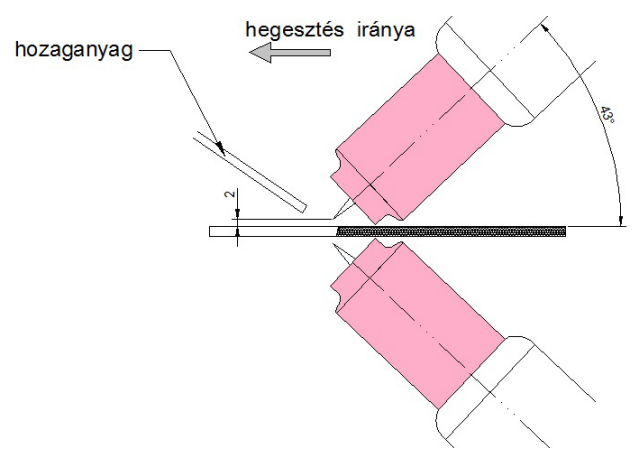

3. ábra. ,Return” TIG eljárásváltozat

Ebben az esetben a höbevitel a két oldalról összegződik, s az közel megegyezik az egy oldalról végzett hegesztésekével. Az eljárásváltozat megvalósítható hozaganyag-gal és anélkül is. A kísérleteinkben a koronaoldalon nagyobb áramerősséget alkalmaztunk a gyökoldalihoz képest, ami föként abban az esetben indokolt, ha hozaganyagot is használunk. A hegesztés gyökoldalán egyenletes beolvadás tapasztalható, $\mathrm{s}$ ez a technológia fö előnye.

A fajlagos hőbevitel (szakaszenergia, vonalenergia) szokásos számítási képlete: $\mathrm{q} / \mathrm{v}=\mathrm{k} \cdot \mathrm{U} \cdot \mathrm{I} / \mathrm{v}_{\mathrm{h}}$, ahol $\mathrm{k}$ a höhasznositási tényező közelítő (átlagos) értéke (TIGhegesztésre $\mathrm{k} \approx 0,6$ ), $\mathrm{U}$ az ívfeszültség $\mathrm{V}$ ban, I a hegesztóáram erőssége A-ben, $\mathrm{v}_{\mathrm{h}} \mathrm{a}$ hegesztési sebesség $\mathrm{mm} / \mathrm{s}$-ban, így a mértékegysége $\mathrm{J} / \mathrm{mm}$. A hőbevitelnek ez a meghatározása pontatlan lehet, mivel a kísérletek során több fontos höbevitelt befolyásoló tényező is felmerül, de ezek pontos hatását a $\mathrm{k}$ értékére jelen keretek között nem tudtuk vizsgálni. Ilyen például a rézalátét alkalmazása, vagy a „Return” eljárásnál a két pisztoly együttes használata. $\mathrm{Az}$ elvégzett kísérleti hegesztések fö paramétereit az 1. táblázat foglalja össze.

1. táblázat. Kisérleti hegesztések fö paraméterei

\begin{tabular}{|c|c|c|c|c|c|}
\hline 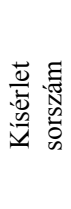 & $\begin{array}{c}\text { Kísérlet } \\
\text { megjelölés }\end{array}$ & 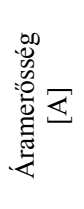 & 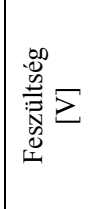 & 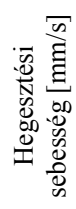 & 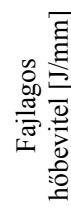 \\
\hline 1. & SS.A.mb.L & 90 & $11 \pm 1$ & 1,9 & 310 \\
\hline 2. & SS.A.mb.H & 110 & $11 \pm 1$ & 2,6 & 280 \\
\hline 3. & SS.A.gb.L & 90 & $11 \pm 1$ & 2,0 & 303 \\
\hline 4. & SS.A.gb.H & 110 & $11 \pm 1$ & 2,4 & 299 \\
\hline 5. & SS.Tr.mb.L & 80 & $11 \pm 1$ & 1,9 & 286 \\
\hline 6. & SS.Tr.mb.H & 100 & $11 \pm 1$ & 2,4 & 280 \\
\hline 7. & SS.Tr.gb.L & 80 & $11 \pm 1$ & 1,8 & 295 \\
\hline 8. & SS.Tr.gb.H & 100 & $11 \pm 1$ & 2,2 & 295 \\
\hline 9. & R.A.L & $55 / 35$ & $11 \pm 1$ & 1,8 & 325 \\
\hline 10. & R.A.H & $70 / 40$ & $11 \pm 1$ & 2,4 & 297 \\
\hline 11. & R.Tr.L & $55 / 25$ & $11 \pm 1$ & 1,4 & 391 \\
\hline 12. & R.Tr.H & $65 / 35$ & $11 \pm 1$ & 2,1 & 319 \\
\hline
\end{tabular}

\section{Mechanikai vizsgálatok}

A kötések mechanikai vizsgálatához szakító próbatesteket - minden egyes kísérleti hegesztésből hármat-hármat munkáltunk ki a $250 \quad$ x $300 \quad$ mm-es hegesztett lemezekből. Ezeket gépi lemezollóval elődaraboltuk, majd egyetemes marógéppel készre forgácsoltuk (4. ábra).

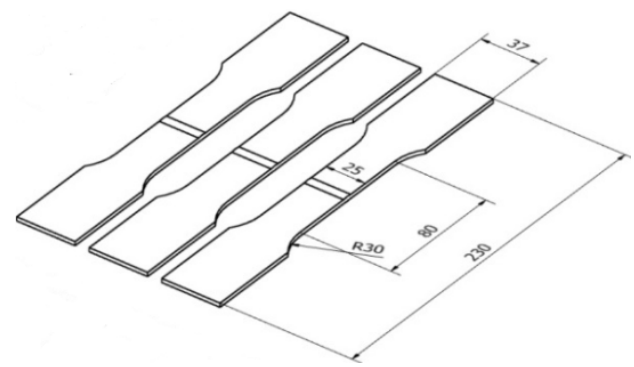

4. ábra. Vizsgálati próbatestek

A vizsgálatokat szabályozott hajtású, TTM100 típusú orsós szakítógéppel 
végeztük. A tizenkettő különböző technológiai kísérlet kötéseiből származó három-három próbatest szakítóvizsgálati eredményeit átlagoltuk. A hegesztett kötések szilárdsági jellemzői (folyáshatár, szakítószilárdság,) minden esetben meghaladták az alapanyagra elöírt minimum értékeket $\left(\mathrm{R}_{\mathrm{p} 0.2}=210 \mathrm{MPa}, \mathrm{R}_{\mathrm{m}}=520 \mathrm{MPa}\right)$.

A hozaganyag nélkül hegesztett (1-4. sorszámú) kötések szilárdsági értékei közel azonosak az alapanyagéval, és a szakadás az alapanyagban történt. A töretfelület szívós törést mutat, a duktilitási (szakadási nyúlás és kontrakció) értékei hasonlóak az alapanyagban mértekkel (2. táblázat).

2. táblázat. Vizsgálati eredmények

\begin{tabular}{|c|c|c|c|c|}
\hline $\begin{array}{l}\text { Kísér- } \\
\text { let } \\
\text { sor- } \\
\text { szám }\end{array}$ & \begin{tabular}{|c|} 
Egyezmé- \\
nyes fo- \\
lyáshatár \\
$\mathrm{R}_{\mathrm{p} 0.2}$ \\
{$\left[\mathrm{~N} / \mathrm{mm}^{2}\right]$}
\end{tabular} & $\begin{array}{c}\text { Szakí- } \\
\text { tószi- } \\
\text { lárdság } \\
\mathrm{R}_{\mathrm{m}} \\
{\left[\mathrm{N} / \mathrm{mm}^{2}\right]}\end{array}$ & $\begin{array}{c}\text { Szaka- } \\
\text { dási } \\
\text { nyúlás } \\
\text { A } \\
{[\%]}\end{array}$ & $\begin{array}{c}\text { Kon- } \\
\text { trakció } \\
Z \\
{[\%]}\end{array}$ \\
\hline 1. & 332 & 670 & 47 & 61 \\
\hline 2. & 332 & 666 & 47 & 59 \\
\hline 3. & 328 & 667 & 50 & 60 \\
\hline 4. & 336 & 683 & 46 & 59 \\
\hline 5. & 333 & 623 & 30 & 49 \\
\hline 6. & 335 & 646 & 38 & 50 \\
\hline 7. & 333 & 654 & 37 & 52 \\
\hline 8. & 329 & 670 & 45 & 56 \\
\hline 9. & 344 & 664 & 46 & 53 \\
\hline 10. & 332 & 664 & 41 & 55 \\
\hline 11. & 321 & 659 & 36 & 51 \\
\hline 12. & 339 & 638 & 33 & 50 \\
\hline
\end{tabular}

A hozaganyaggal hegesztett (5-8. sorszámú) kötések szilárdsági értékei kis mértékben elmaradnak az első csoporthoz képest, lényeges különbség a szakadási nyúlásban és kontrakcióban van. Ezen csoportnál minden esetben a varratban történt a szakadás, a töretfelület párhuzamos a varratvonallal. Az 5-ös számú próbadarab átlagosnál alacsonyabb szakadási nyúlása a hiányos beolvadás eredménye.
A „Return” eljárásváltozattal készült varratoknál a hozaganyag nélküli (9-10. sorszámú) próbadarabok nagyobb szakítószilárdságot és szakadási nyúlást mutatnak, mint a hozaganyaggal készültek (11-12. sorszámúak). Minden esetben a varratban történt a szakadás, de ezt nem beolvadási hiba okozta.

\section{Következtetések}

A mechanikai vizsgálatok során mért eredmények egyértelmüen megmutatták, hogy a varratok szilárdsági értékei jó egyezést mutatnak az alapanyagéval, így az anyagminőségre elöírt minimum feltételeket teljesítették.

A szakítóvizsgálat további tanulsága, hogy az egyoldali autogén eljárással készült varratok az alapanyagban szakadtak el, eltérően a többi eljárásváltozattól, melyek során a szakadási helyek a varratba estek. A töretfelületek minden esetben szívós törést mutattak, $\quad 50-60 \%$ közötti jelentős kontrakcióval.

\section{Szakirodalmi hivatkozások}

[1] Gáti József, Kovács Mihály: Kötéstechnológia, Óbudai Egyetem BL 516, Budapest, 2010

[2] Harold M. Cobb: The History of Stainless Steel, ASM International Materials Park, Ohio, 2010

[3] J. Redmond - R. Davison: The evolution of high performance stainless steels, International Molybdenum Association, London

[4] Curtis W. Kovach: High-Performance Stainless Steels, International Molybdenum Association, Pittsburgh

[5] Thomas J. Leinert, Sudarsanam Suresh Babu, Thomas A. Sievert: ASM Handbook Welding Fundamentals and Processes, ASM International, 2011

[6] Kovács Mihály: Hegesztés, Nemzeti Tankönyvkiadó, Budapest, 2012

[7] Szerkesztette Gáti József: Hegesztési Zsebkönyv, COKOM Kft, Miskolc, 2003 